\title{
Chapter 20 \\ Cultural Translation as a Multidirectional \\ Process in the Seventeenth-Century \\ Madurai Mission
}

\author{
Giulia Nardini
}

\subsection{Introduction}

Early modern history is often conceptualized as an age of migrations, interconnections, cultural mobility, "modernity", and emerging nation-states, but also as an epoch that saw intensified forms of hierarchy, the slave trade, and forms of political articulation such as empire. ${ }^{1}$ On the macro-level, my research aims to explore the transcultural dimension of early modern historical events. ${ }^{2}$ The lens of transculturality reveals how every micro and macro context is internally hybrid and inhabited by different social groups, allowing us to transcend the monolithic idea of cultural identity and to embrace the dynamism of cultural encounters. As Pascal Boyer points out: "People communicate with other people, they meet individuals with similar or different notions or values, they change or maintain or discard their ways of thinking because of these encounters, and so forth, what we call their 'culture' is the outcome of all these particular encounters." 3 In these interconnected areas where different cultures meet, boundaries are crossed, ideas

\footnotetext{
${ }^{1}$ Koselleck (2007), pp. 154-169.

${ }^{2}$ For more information about the concept of "transculturality" see Welsch (1999) and Juneja and Kravagna (2013).

${ }^{3}$ Boyer (2007), p. 30.

G. Nardini $(\bowtie)$

Universität Bielefeld, Bielefeld, Germany

E-Mail: giulia.nardini@uni-bielefeld.de

(C) Der/die Autor(en) 2021

401

R. Toepfer et al., Übersetzen in der Frühen Neuzeit - Konzepte

und Methoden / Concepts and Practices of Translation in the

Early Modern Period, Übersetzungskulturen der Frühen Neuzeit 1,

https://doi.org/10.1007/978-3-662-62562-0_20
} 
are connected, concepts are translated, and new kinds of barriers or transcultural factors are produced, ${ }^{4}$ Homi Bhabha reminds us "that it is the 'inter', the cutting edge of translation and renegotiation, the in-between space, that carries the burden of the meaning of culture. [...] And by exploring this Third Space, we may elude the politics of polarity and emerge as the others of our selves". 5

My focus is on the "contact-zones" 6 and "translation-zones"7 of the Jesuit missions in South India in the seventeenth century. The missionary context is conceived as a social space where encounters between heterolingual agents established a flow of ideas, a movement of doctrines, and a communication of meanings. On this micro level, my research concerns the translation of religious discourse. Religion plays a central role here: it can be either an instrument of communication, a way of circulating knowledge, or a symptom of cultural incommensurability and un-translatability. Religious objects, doctrines, practices, and rituals must be transferred into a different language and cultural code. As the word's etymological root implies, "translation" (from Latin translatus, participle of transferre, 'to bring' or 'to carry across') refers to a transposition of sacred objects (relics above all) which encompass an equivalent sacrality in a different place. As cultural transfer, the process of translation is a multidimensional, metalinguistic, and performative act, aptly labelled "cultural translation" ${ }^{8}$ It is a re-codification of an equivalent semantic in a different semiotic context, with the assumption that the sources will still be present in one form or another in the reformulated version.

My analysis of the mechanism of translating religious beliefs in missionary areas seeks to illuminate the debate on the notions of the function and orthodoxy of the translations. Indeed, the translation process is a creative act which transfers the translation not as a form of identity but as an equivalence: the result of a translation is not identical but equivalent to the source. Among multiple alternatives, the choice of the equivalent translation depends on the function and the actors involved in the translation. As Venuti explains: "Function has been understood as the potentiality of the translated text to release diverse effects, beginning with the communication of information and the production of a response comparable to the one produced by the foreign text in its own culture. [...] Function is a variable notion of how the translated text is connected to the receiving language and culture."9

\footnotetext{
${ }^{4}$ Said (1996), p. 24; Welsch (1995), p. 39.

${ }^{5}$ Bhabha (1994), pp. 38-39.

${ }^{6}$ Pratt (1991), p. 34.

${ }^{7}$ Apter (2006), p. 6.

${ }^{8}$ Most relevant is the work of Burke (2007). Cf. also: Cronin (1996); Hsia (2007); Lutter (2014), pp. 155-167.

${ }^{9}$ Venuti (2012), p. 251.
} 
In the missionary context the process of translating primarily involves four functions. ${ }^{10}$ The missionaries act as intercultural brokers in a twofold process of translation: they translate religious texts, practices, and rituals to the local audience in order to communicate Christianity to the local people (function 1); at the same time, they translate texts, practices, and rituals from local cultures to absorb local languages and social practices and report this knowledge to their ecclesiastical superiors (function 2). Subsequently, the local agency takes part in the process of translation: it translates itself to establish communication with the missionarytranslator, and it translates the missionary translation into its own patterns of meaning and culture (function 3). ${ }^{11}$ The missionary translation has a wide resonance; it builds the transcultural characteristics of Christianity (function 4).

Therefore in this process the missionary-translator is the author and the first actor of the translation. In the analysis of the first two functions, the focus is on the multidimensional task of the missionary-translator of negotiating complex linguistic and cultural differences. Because semantic relationships are ineffable, the author-translator navigates between the poles of successful mediation and incommensurability, establishing something new as transcultural or rather marking the boundaries of the untranslatable. "Untranslatability" has been defined by Benedetto Croce as a result of the specific genius of each language; ${ }^{12}$ in other words, as something that resists translation. This is a pivotal topic in the missionary context, where the problem of untranslatability is strongly connected with the question of religious "orthodoxy". In the translation of religious texts and practices, equivalence to the source is the prerequisite for preserving theological "truth" and conformity to the Church's orthodoxy. The difficulty of achieving theological equivalence generates the problem of the untranslatability of theological concepts. From the perspective of cultural translation, an untranslated concept is an authoritative act of bringing the translation close to its source, its message, and its embedded power. An untranslated transliteration, which is quite common in translated missionary texts, is an interesting element for historical analysis: it can reveal a difficult correspondence of meaning between the respective cultural codes, it can be an instrument for maintaining conformity to a theological orthodoxy, and it can be a strategy for imposing the cultural predominance of the source's hierarchy of power (further explanations in the next paragraph). ${ }^{13}$

Moreover, translation is never a one-way process, but rather a reciprocal process of exchange. In the analysis of the third function, the focus is on the

\footnotetext{
${ }^{10}$ Cf. Flüchter (2018), p. 8.

${ }^{11}$ On attempts at translating Catholicism in India see Bayly (1992). For a Japanese example see Abé (2017).

${ }^{12}$ Burke (2007), p. 25.

${ }^{13}$ Venuti (2012).
} 
host culture and the ways in which it accommodates and discloses itself to the translator. It transfers categories, genres, and structures into the grids of the translator's semantic codes. Evangelization cannot be conceived as a mere topdown process, but is a negotiation ${ }^{14}$ of practices and beliefs that involves many actors in the process of translating and conveying the transcultural dimension of religion. This effort of translation, accommodation, and negotiation is not separate from the political sphere, as "the deep devotion to a particular mission space did not preclude the missionaries from attending the universal aspirations of the Church or the global ambitions of their imperial patrons". ${ }^{15}$ Translation is both an individual act and a refraction of powers. The process of translation is furthermore influenced by indirect actors: the hierarchies of power. In order to examine the fourth function, the circulation and reception of the translation in a global space must be traced. "Cultural translation" is a reflexive discourse that modifies the respective actors involved in the process. Its reception has resonance and a power of change not only in the directly involved agencies, but also in the indirect and secondary addressees: the Roman Church, the Society of Jesus, the Portuguese Padroado, and the Brahman and Nāyaka social groups. Furthermore, cultural translation is a tool of analysis which leads to crucial questions: ${ }^{16}$ How do the actors communicate, negotiate, and build a transcultural identity in a specific act of cultural encounter? How do the involved actors translate and accommodate themselves in order to understand each other? How can religious concepts or categories be translated to different languages and cultural contexts?

The case study that I undertake concerns the missionary experience and cultural translation of Roberto Nobili SJ (1577-1656). This Jesuit missionary engaged in a twofold "cultural translation" in Madurai. As a transcultural actor and cultural broker, he tried to translate, explain, and accommodate local Tamil cultural and religious practices to a European audience in order to justify his missionary practices, just as he had translated, explained, and accommodated the Latin Catholic doctrine to the Tamil people of South India in order to evangelize them. During his fifty years of missionary service (1606-56), Nobili established a dialogue with the local Tamil community in the multicultural and multilingual context of the Madurai mission, translating and reshaping Catholic doctrine into a new model of Tamil Catholicism. ${ }^{17}$

From a global perspective, the Madurai missionary context is a particularly promising field of analysis. In order to comprehend and study these macro

\footnotetext{
14“'Translation implies 'negotiation', a concept which has expanded its domain in the last generation, moving beyond the world of trade and diplomacy to refer to the exchange of ideas and the consequent modification of meaning. The moral is that a given translation should be regarded less as a definitive solution to a problem than as a messy compromise, involving losses or renunciations and leaving the way open for renegotiation." Burke (2007), p. 9.

${ }^{15}$ Chakravarti (2018), p. 10.

${ }^{16}$ Flüchter (2018).

${ }^{17} \operatorname{Nardini}(2017)$.
} 
phenomena we have to zoom the focus on the micro-level, on the micro-voices of those who inhabited 'localities', peripheries and spend our effort to transcend them not only in a comparative perspective but in a transcultural perspective, seeking out the fragile threads that connected the globe, by tracing network and process of circulation in which our local voices are already plugged into. ${ }^{18}$ Madurai was on the periphery, far from Rome, the centre of Roman Catholicism, and at some distance from Goa, "the Rome of the Orient", i.e. the institutional and political centre of Latin Catholicism and the Portuguese Empire in India. Notwithstanding its peripheral location, the Madurai mission was situated at an intersection of historical connections: the Jesuit missionary strategy, the Portuguese empire, and the local Nāyaka kingdom. In particular, it became the centre of a bitter controversy about the missionary strategy of accomodatio. ${ }^{19}$

Nobili's missionary strategy has been perceived by numerous scholars as a pivotal example of the "accommodation method". ${ }^{20}$ It has either been lauded as tolerant for its adaptation to local Tamil culture or damned for its deviation from standard Christian evangelization practices and the missionary's transformation into a local Tamil guru (a spiritual, religious, philosophical guide, teacher, or master). His case generated a controversy about the orthodoxy of his missionary method. After thirteen years (1610-1623), accomodatio was eventually recognized as orthodox by a Papal Bull in 1623. Nobili's case has often been studied in apologetic terms and under a binary normative perspective of "orthodoxy" vs. "unorthodoxy". On a different note, my own research frames Nobili's missionary life as a case study of "cultural translation", and from this perspective it investigates the previously mentioned four functions of translation in his method: How did Nobili translate Roman Catholicism for a Tamil audience? How did he translate the Tamil customs for the Roman curia? Which actors were engaged in the translation process? What was the reception and resonance of Nobili's translation in the global context? Furthermore, since the process of translating religion is of historical relevance, it is of special interest to examine how the religious encounter was mediated by the process of translation and therefore what role "cultural translation" played in the construction of social identities. The act of translation is central in the process of outlining religious concepts and traditions. ${ }^{21}$ Religion and translation are often defined in their identity with a specific group pattern and with an "original". But religions and translations are dynamic phenomena in a constant state of redefinition. It is important to investigate how the definition of religions is based on the process of translating religious concepts and categories and how different translations have shaped different understandings of religions in the past and may continue to do so in the present.

\footnotetext{
${ }^{18} \mathrm{Cf}$. Subrahmanyam (1997).

${ }^{19}$ Županov (1999).

${ }^{20}$ Cf. Rajamanickam (1972); Saulière (1995).

${ }^{21}$ Israel (2019).
} 


\subsection{A Model of Cultural Translation as an Analytical Tool $^{22}$}

Cultural translation is not only an object of research, but also a tool of analysis. It allows us to investigate how the transcultural dimension is developed, where linguistic and cultural differences are mediated, and when, on the contrary, they create misunderstandings, conflicts, and boundaries of the "speakable". In order to unravel the mechanism of translation, Antje Flüchter and I have compiled an analysis toolkit built on translation studies theories drawn primarily from Eugene Nida, Gottlob Frege, André Lefevere, and Lawrence Venuti. ${ }^{23}$ I apply this analytical tool to my case study, namely Roberto Nobili's practices of translation in seventeenth-century South India, in order to describe the functions of translation and the development of the transcultural characteristics of Catholicism.

Eugene Nida (1914-2011) explains that translation must satisfy the four basic requirements of (1) making sense, (2) conveying the spirit and manner of the "original", (3) having a natural and easy form of expression, and (4) producing a similar response. But as no language corresponds perfectly to any other, there is no completely exact translation, only different types of equivalence. It is obvious that, at certain points, content and form (or meaning and manner) will come into conflict, and that one or the other must give way.

For this reason Nida describes two basic orientations in translating, which produce two kinds of equivalence: dynamic equivalence (D-E) and formal equivalence ( $\mathrm{F}-\mathrm{E})$. In the case of $\mathrm{D}-\mathrm{E}$, the focus of attention is on the message and directed towards the receptor's response, whereas F-E is basically formal and source-oriented, i.e. it is designed to reveal as much as possible of the form and content of the source message. An F-E translation should match the different formal elements in the source language as closely as possible and respect standards of accuracy and correctness; it is designed to permit the reader to identify him- or herself as fully as possible with the source-language context and to understand as much as possible the customs, manners of thought, and means of expression. Nida perceives the aim of the missionary-translator as D-E. This is based upon the "the principle of equivalent effect". ${ }^{24}$ "The relationship between receptors and message should be substantially the same as that which existed between the original receptors and the message." ${ }^{.25}$ A Christian missionary cannot change Christian belief in a fundamental way, because his translation needs to be faithful.

\footnotetext{
${ }^{22}$ This model has been defined together with Prof. Antje Flüchter.

${ }^{23}$ Cf. Flüchter (2018).

${ }^{24} \mathrm{Nida}$ (2012), p. 136.

${ }^{25} \mathrm{Nida}$ (2012), p. 129.
} 
Moreover, the texture of D-E can be grasped more thoroughly if we connect Nida's theories with the studies of Gottlob Frege. ${ }^{26}$ Every translation is a transfer of semantics from one linguistic and cultural code to a different one; in the structure of a language/cultural code, the meaning is carried by semantic units. These are like semantic boxes, constituted by the sign (the form, the morpheme, the word), the reference (the object, the entity) and the sense or senses (its meaning/s). Translation creates an equivalent semantic box which corresponds in some way to the sign, the reference, or any of the senses of the source. It can carry an equivalence of meanings, sacrificing the form, or conversely it can maintain form while conveying a different meaning.

The process of translation is a process of mediation: the translator detects a tertium comparationis, selecting a transferable specific element, between the different meanings of the source semantic box. The selection is like a common element, which retains a connection with the target context and is accommodated and re-codified into the target semiotic code. ${ }^{27}$ Afterwards the translator adopts or creates an auxiliary morpheme, a sign/form, which reshapes the selected sense, or refers to the equivalent object in the target culture. For example, different translators have selected diverse meanings of the concept of the Eucharist, such as "food offering", "Great Miracle", or "Great Compassion", in order to translate it into different cultural contexts. ${ }^{28}$ Nida defined the result of this process as "dynamic equivalence", the appropriation of something alien that is related to the target context by the principle of equivalent effect.

Collecting and analysing the different elements of F-E or D-E translation reveals important historical issues. Roberto Nobili translated himself as a missionary, his self-fashion and ministry by formal and dynamic equivalences. Few elements are transferred as F-E, while his list of D-E is long. Crucially, it is the comparison of $\mathrm{F}-\mathrm{E}$ and $\mathrm{D}-\mathrm{E}$ translations (which I will discuss in this article) that triggers important historical questions: Which concepts were translated as F-E or D-E? What were the selection criteria? Was the equivalence oriented and targeted? To what kind of cultural context and audience does it refer?

As we have already mentioned, translation is neither individual nor neutral; it is a political act determined by an articulated polyphony of different characters, social groups, and hierarchies of power. In order to investigate the actors and factors embedded in the process of translation, the theory developed by Lawrence Venuti (b. 1953) is helpful. Based on Schleiermacher, Venuti refined the concepts of "domestication" vs. "foreignization". ${ }^{29}$ With the help of these concepts, we

\footnotetext{
${ }^{26}$ Frege (1892).

${ }^{27}$ Koster (2010).

${ }^{28}$ Flüchter, Nardini (2020).

${ }^{29}$ Venuti (2012); Schleiermacher (1816).
} 
can interpret the choice of a translator to place a translated text between two extremes: domestication is the act of bringing the text to the reader, whereas the reader is taken to the text through foreignization. The source is always subjected to a process of domestication, which aims to re-codify it in order to appear familiar to the target audience. This style of translation is transparent and fluent in order to minimize the strangeness of the foreign text to the readers of the target language. The foreignization concept of translation adopts linguistic and conceptual calques or loans from the source language to direct foreign attention to the source. Therefore the act of shaping the translation so that it is either closer to the source code or closer to the target code has great power to draw social and cultural images. The translator is an invisible actor who assumes an active role in the process of translation and the construction of cultures and societies. The translator who chooses a translation method decides which characteristics of both the source and target cultures should prevail and be communicated through the translation. In the act of foreignization, the translator codifies how the source's alterity is characterized and ascribed. Furthermore, through the act of domestication, the translator disseminates foreign characteristics, values, beliefs, and representations inscribed in the translation. As mentioned above, this is not merely an individual and neutral act, but is directly or indirectly determined by different authorities and political aims. Research into strategies of foreignization and domestication is useful to unveil hidden power asymmetries, power structures, and their relevance for the participating languages or cultures. ${ }^{30}$

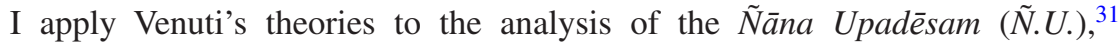
the lifetime's work of Roberto Nobili, written in Tamil (with a Sanskrit/ Tamil lexicon), which has never been studied and translated before. This is a compendium for teaching Catholic doctrine to a Tamil audience. $\tilde{N}$. U. contains a pioneering and incisive new Christian terminology in Sanskritized Tamil. Here the author/translator re-shapes Catholic concepts in the Tamil and Sanskrit languages, placing his translation in the broad spectrum between the two opposite poles of domestication and foreignization. Baptism, translated as

\footnotetext{
${ }^{30}$ Venuti (2012), p. 473.

${ }^{31} \tilde{N} \bar{a} n a$ Upadēsam, ambiguously labelled by librarians as Catechismus Romanus, composed by Roberto Nobili from 1605 to 1656 . A copy of the manuscript is in the Bibliothèque nationale de France, Paris: R. Nobili, Catechismus Romanus (Nânayupadecam), Tamil, manuscript on paper, 1720, Indien 459, fol. 1-366 and R. Nobili, Catechismus Romanus, tertia pars, Tamil, Indien 460, fol. 1-362. A Portuguese translation by Baltasar Da Costa in 1661 (published in 1667), is available at the Academia das Ciências de Lisboa. The first edition of Ñanna Upadēsam was printed in Ambalakhad in 1675-76 and published in 1677. A copy is conserved in the Goa State Central Library. A modern edition is Roberto Nobili, Ñāna Upadēsam, ed. S. Rajamanickam, 3 vols. (Tuticorin, Tamil Literature Society, 1966). While I have translated and analysed the Tamil manuscript and the different editions, here I quote from my English translation of the Ambalakhad editio princeps.
} 
ஞானஸ்நானம் [ñāña snāñam] 'bath of knowledge', is a good example of a domesticated concept. Other cases, like the translation of 'Holy Spirit' (Ispirìttu Sāntu -Tamil: இஸ்பிரீத்து சாந்து), show a foreignizing approach. The two poles of domestication and foreignization mark the boundaries of a vast collection of terms and open historical questions: Why was the term Holy Spirit not translated but only transliterated? Is this a case of "untranslatability" and "incommensurability"? What translation politics and translation policies are involved in the choice of F-E or D-E?

During the "process of decoding and reformulating" 32 certain rules are observed. These depend on different factors, such as the actual situation, the function of the translation, the patrons and the addressees. Beside these aspects, André Lefevere ${ }^{33}$ argues that the translator has to choose adequate formal rules and textual and conceptual grids in order to enable the reader to understand the translation. ${ }^{34}$ Textual grids are a sort of "text marker" that indicate what kind of text the reader must expect. A common example is "Es war einmal" ('Once upon a time'), which evokes a fairy tale. The textual grids show a shared symbolic repertoire in a literary context, while the conceptual grids depict adequate semantics, concepts known by the target audience into which the translator has to fit the content. Owing to these grids, every translation becomes the "primary instrument through which one culture both learns about another, but at the same time constructs its image of that other culture." 35 For Lefevere, these grids refer to a rather general and fundamental perspective, like a colonial or religious framing of perception and presentation. ${ }^{36}$ The present paper uses this concept more broadly: it assumes that translators not only translate in a special mental setting (of their own or their audience), but also refer to or choose specific concepts and thereby structure the understanding of their readers (as is explained below).

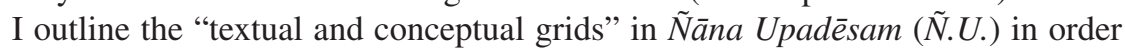
to grasp information about the literary and semantic contexts behind the translation, to trace which literary genres resulted, and which topics are emphasized. Here the different textual markers reveal a complex refraction of different literary genres borrowed by Nobili from Latin, Sanskrit, and Tamil literature: moral books, mythology, epics, folk tales, theology, philosophy, commentary, Biblical texts, catechisms, and prayer books. Catholic textual and conceptual grids are carefully selected and shaped in connection with Hindu literary genres. From this perspective, $\tilde{N} . U$. reveals interesting insights about the social context in which

\footnotetext{
${ }^{32}$ Lefevere (2002), p. 75.

${ }^{33}$ Lefevere (2002).

${ }^{34}$ Lefevere (2002), p. 76.

${ }^{35}$ Bassnett (2013), p. 31.

${ }^{36}$ Lefevere (1998), p. 77.
} 
Nobili worked and situated his missionary translation practices and the ways in which the images of the involved actors are framed. This analysis seeks to embrace the Tamil as well as the Roman context.

\subsection{The Dynamic Equivalence (Nida) of a Jesuit Missionary Model in South India}

If dynamic equivalence is usually applied as a metaphor to describe the translation of texts, the current research widens its application to the analysis of the translation of religious practices. Roberto Nobili faced the task of translating his character, his role, and his purpose as a Jesuit missionary into the code of seventeenth-century South Indian society. Nobili undertook a metamorphosis into a Tamil alter ego which can be better understood and analysed by using the concept of dynamic equivalence. He changed his name to Tattuva Pōtakar (Tamil: தததுவ தபாதகர, 'The Teacher of Reality'). He also made a serious effort to adopt the lifestyle of the local community by following a vegetarian diet and practising ritual bathing before eating and performing religious worship. He spent much of his time meditating and concentrating on the study of local languages and texts. $^{37}$

As part of an apologetic and eulogising media campaign, Nobili and his companions wrote letters and reports to convey his image as a Tamil Jesuit apostle. The Jesuit propaganda aimed to construct a missionary model of sainthood, variously defining Nobili as a Roman Raja, a Jesuit brāhman, or a Catholic $\operatorname{sanny}_{\bar{a}} \sin ^{38}$ (a Hindu ascetic, a renouncer). ${ }^{39}$ Alberto Laerzio, the Jesuit superior of Malabar Province, provided a detailed portrait of Nobili's attire to the Roman authorities: "The dress of Father Robert consists in a long toga of pale yellow colour like a cabana which reaches down to his feet. Over it he wears a rochet of fine linen of the same colour; and over the rochet he throws over his shoulders a cloth either red or of the same colour as the gown. On the head he wears a cloth of linen, like a round biretta, while from his neck hangs a cord made of five threads, three of gold, and two of white linen with a cross which falls on his breast." ${ }^{20}$

\footnotetext{
${ }^{37}$ Cf. Rajamanickam (1972), pp. 26-27; Saulié́e (1947), p. 169; Ferroli (1955), p. 12.

${ }^{38} \mathrm{~A}$ sannyāsin is an ascetic or renouncer: "literally a man who has forsaken all, and who has renounced the world and leads a life of celibacy, devoting himself to religious meditation and abstraction, and to the study of holy books. ... He is the fourth Âsrama or final stage of life recommended for the three higher orders. The number of Brāman Sanyāsis is very small; they are chiefly the Gurus or High Priest of the different sects" (Cf. Thurston vol. VI, p. 188).

${ }^{39} \mathrm{Cf}$. Županov (1999).

${ }^{40}$ Rajamanickam (1972), p. 23.
} 
Fig. 20.1. ACL, Série

Vermelha, Cod. 698 , fol. $224^{\text {r }}$

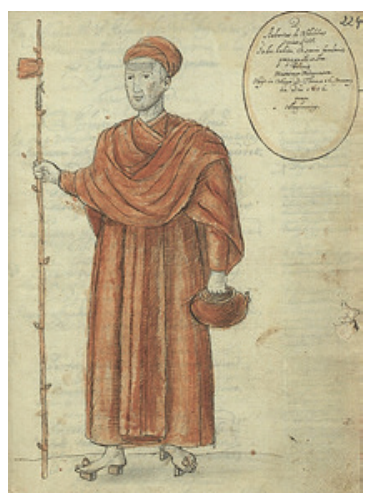

In another letter, Laerzio reported an admonition to Nobili by a local Pandāram (a term used to denote any non-Brāhman priest):41 "If your object is only to save your soul, you can go about dressed as you please, but if you want to be a master among these people, teach them the spiritual law, and gather a large number of disciples, you must, as far as you can, adapt yourself to the manners, customs and ideas of this country." 42 Another coeval Jesuit missionary in Madurai, Baltasar da Costa, drew a portrait of Nobili in which the image of the missionary is clearly seen in the features described by Laerzio (Fig. 20.1).

In 1649, a missionary in the Mysore region (corresponding to the southern part of modern Karnataka) wrote a letter that demonstrates the circulation of Nobili's missionary model throughout South India: "Here I dressed like Fr. Martins

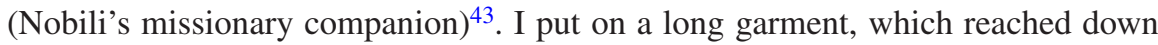
to the feet, and tied my loins with a cloth, but without any knots, and threw a kind of cape on my shoulders, and a turban on my head. No boots, but barefooted, no shirt and no cloak. A stick in the right hand, with a little flag on top - a sign of poverty; in the left a round vessel, called camandola. I bored my ears, and covered head and neck with ashes. This is the dress of a sannyāsin". ${ }^{44}$

Conversely, from the perspective of cultural translation, Nobili did not adopt and align himself with any existing local South Indian pattern, but performed a new model of Tamil Catholic missionary, thereby creating a transcultural personality, a "third space of in-betweenness" which differed from the respective

\footnotetext{
${ }^{41}$ Brāhman is a member of the Hindu social group of Brāhmans, generally the cultural and religious elite group. Cf. Thurston and Rangachari (1909), I, p. 169; Pandāram is a name used to refer a non-Brāhman priest. Cf. Thurston and Rangachari (1909), VI, p. 26.

${ }^{42}$ A. Laerzio to Acquaviva 'Relatione di Madurè', 20 November 1609 ARSI GOA 54a, fol. 2-16.

${ }^{43}$ Cf. Rajamanickam (1972), p. 272.

${ }^{44}$ A. Buccerio to Aquaviva, 3 October 1610, ARSI, Goa 51, fol. 110-15 (1st via) 116-22 (2nd via), lat (3rd via) in Goa 53, fol. 40a-40y. Cf. Rajamanickam (1972), p. 23.
} 
actors (the Jesuit missionary and the Tamil sannyāsin) but stood in a relationship of dynamic equivalence with them. The morphology of the Roman Jesuit missionary was re-codified into Tamil habits and customs. The author domesticated the alterity carefully without transforming himself into any local religious character. Instead, he established the closest natural equivalence to the source message and receptor's response. He depicted and isolated the tertium comparationis, the transferable elements of a Jesuit Tamil missionary as a preacher, a spiritual guide, a theologian. He established a dynamic equivalence of these contents in the forms of the Tamil code, adopting and adapting practices and emblems of sannyāsin, brāhman, and rāja. His fellow missionary Antonio Vico ${ }^{45}$ reported what Nobili wrote on a palm-leaf strip posted on a tree in front of his church in 1609: "I came from Rome; my family in Rome corresponds to that of good Rajas in this land. When I was young I became a sannyāsin and a man of religion."46

Analysing the elements of Nobili's Tamil missionary model, we observe twofold dynamic equivalences: (1) He selected and accommodated the characteristics of the Jesuit missionary into the Hindu Tamil grids; (2) he reshaped and re-codified the characters of brāhman and sannyāsin into the Roman Catholic code. Indeed, he imitated and transformed the appearance of a sannyāsin and decorated himself with brahmanical distinctive signs modified by Catholic images. For example, he adopted the pūnūl, a cord worn from the shoulder to the opposite side, surrounding the torso. In some Hindu traditions this cord used to be received by upper-caste religious disciples during the upanayana, one of the most significant rites of passage (samskāras) in Hindu religious life. Secondly, Nobili decorated his forehead with a tilaka, a sign drawn with sandalwood paste, generally defined by different lines to represent the different religious schools. Furthermore, Nobili fashioned his hair with a kudumi, a tuft of hair falling on one or the other part of the head while the rest of the head is shaved, as a sign of affiliation to a brāhman group. In order to adopt these practices, Nobili transformed and accommodated them to the grids of Roman Catholicism: he exchanged the two brahmanical linen lines for three threads representing the Catholic Trinity and suspended a crucifix from them. Moreover, he drew a type of tilaka very similar to that of the Śaiva Siddhänta school, ${ }^{47}$ namely the one holding the "monistic" philosophy that Nobili often compared to Catholicism. ${ }^{48}$ He adopted the emblems of a brähman although he did not attain any social affiliation, lineage, or samskäras. ${ }^{49}$ Furthermore, he adopted the vest of a

\footnotetext{
${ }^{45}$ Rajamanickam (1972), p. 275.

${ }^{46}$ Vico, A. to Laerzio, A., 27 May 1611, in Laerzio, A, to Aquaviva, C, Cochin (It.), 25 November 1611, ARSI, Goa 54a, fol. 93-129.

${ }^{47}$ Goodall (2004).

${ }^{48}$ Bachmann (1972).

${ }^{49}$ Aranha (2010).
} 
sannyāsin although he had not achieved any of the three āśramas (the four stages of the Hindu life) that precede the status of sannyāsin..$^{50}$

In the three Latin treatises ${ }^{51}$ addressed to the Roman authorities, Nobili engaged in a process of camouflaging religious Tamil habits and customs. Playing with different interpretations of religious literature and with the thin line separating the civil and religious semantic fields, Nobili veiled the religious character of his adopted customs. He defined brähmans as the elite intellectual group and the brahmanical emblems as civil signs of social inclusion; ${ }^{52}$ in the same manner, he redefined the model and role of the samnyāsin in terms of the paths of the Catholic priesthood. In his Tamil work N.U., ${ }^{53}$ Nobili criticized the status of sannyāsin as the consequential last stage of Hindu religious life (as it is written in the Sanskrit literature such as Ashrama Upanishad, the Vaikhanasa Dharmasutra and the later Dharmashastra) defining sannyāsin as an independent way of life (as it is in the early Dharmasutras). In lesson fifteen of the second book of $\tilde{N} . U$, he wrote: ${ }^{54}$

Despite what can be said by the ignorant people, one person cannot initiate the life of samnyāsin after having experienced the lust of sexual life and the responsibility of family life. If someone starts the samnyāsin life after all the other experiences, his intimate reason is not to reject the worldly life but it is to find a refuge from the worldly life which has rejected him. Therefore he avoids the desire of lust only in his actions but not in his mind. Even though the married dharma (life) is a perfect way for a man and a woman to realize themselves and follow God's teachings, when a man or a pure woman (paricuttam, n. pari-šuddha., holiness, sanctity, purity, immaculateness) are in total devotion to God they can decide to offer their life to God and to become samnyāsin, both of these lifestyles are perfect. ${ }^{55}$

Nobili reconfigured samnyāsin into the grids of the Jesuit priesthood as divine sacrament, celibacy, mission, and divine mandate: "In order to prevent the consequences of this ignorance, which is widespread, God created religion (Vedam) and samnyāsin. God has sent the people to turn the people to the true religion." 56

\footnotetext{
${ }^{50}$ The Hindu discipline prescribes four consecutive ásramas ('stages') in the life of a man: Brahmācarya ('student'), grhhasthya ('householder'), Vānaprasthya ('retired'), and sa samnnyāsa ('renunciate'). Therefore, following the Mānavadharmaśästra (or Manusmrti, Manu's Code of Law), traditionally the most authoritative book of Dharmashastra ('the book of law;'see Olivelle 2005), the samnyāsin is the one who has already experienced the three other stages. Although different schools interpreted the scriptures in different ways, Sankara (8th-9th century), the founder of the Advaita Vedānta school of philosophy (quoted by Nobili also in N.U.), is said to have chosen a samnyāsa state already in his youth. See Županov (1999), p. 208.

${ }^{51}$ Nobili 1610 in Dahmen (1931); Nobili 1613 in Rajamanickam (1972); Nobili 1619 in Rajamanickam (1971).

${ }^{52}$ Nobili 1613 in Rajamanickam (1972).

${ }^{53}$ Nobili Ñ.U., vol. 2, lesson 15-16.

${ }^{54}$ Nobili Ñ.U., vol. 2, lesson 15-16.

${ }^{55}$ Nobili Ñ.U., vol. 2, lesson 15.

${ }^{56}$ Nobili, Ñ.U., vol. 2, lesson 15-16.
} 
As a dynamic equivalence, the missionary-translator aimed to maintain the principle of the equivalent effect, the relationship between receptor and message, as substantially the same as that which existed between the source receptors and the message (following E. Nida's theory). Therefore, in this twofold process of translation, Nobili transformed the forms and symbols of Tamil society such as samnyāsin and brāhman. On the other side, Roman Catholic religious aspects and practices of the Jesuit missionary are de-codified from the Roman Catholic semiotic code and transferred into the grids of the Tamil Hindu semiotic code. The result is a cultural translation and a transcultural actor, a Tamil Catholic missionary, which has even been defined as a "utopia". 57 From a historical perspective, this analysis reveals pivotal details about the embedded agencies (such as the Roman Church, the Jesuits, the Tamil context, social groups, and hierarchies of power) which will be examined with reference to the other cultural translation theories, then summarized and illustrated in the conclusion to this article.

\subsection{Translating Literature and Literary Genres by Investigating Textual/Conceptual Grids}

My second case study is Nobili's translation of a literary genre. Nobili was a prolific author and his literary production is still almost unknown. The majority of studies about him are based on his Latin works, but in addition to a voluminous correspondence and three treatises in Latin, he also wrote over twenty works in Tamil.

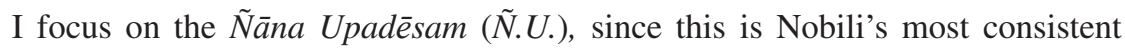
work; it was composed during fifty years of missionary work in South India. This voluminous work, which is divided into three volumes, was written as a compendium for teaching Catholic doctrine to Tamil neophytes. It is not a translation of any pre-existing book or genre, even though it is often catalogued as a catechism or even as a Catechismus Romanus. ${ }^{58}$

In order to understand the character of the $\tilde{N}$.U.'s literary genre, I investigate its textual and conceptual grids as outlined by A. Lefevere. What emerges from the analysis of conceptual grids is a texture of different themes and sources in

\footnotetext{
57Županov (1999).

${ }^{58}$ The leitmotif of this entire collection of missionary catechisms in vernacular languages in 16thcentury South India is the canon of the four main recurring topics of the Catholic catechism, made official by the catechism of the Council of Trent: (1) the explanation of the articles of the creed, (2) the sacraments, (3) the Decalogue (the Ten Commandments), and (4) the prayers. All the missionary catechisms incorporate this four-part canon with minimal variations and some additional topics.
} 
which the translation is embedded. In the $\tilde{N}$.U. each volume is dedicated to a layer in the pyramid of knowledge and truth. This structure follows Aquinas' Summa contra Gentiles (I, 1-9): in the first book he reported the arguments as they can be grasped by the rational mind; the second book is about the topics that can be explained with the support of religious doctrine; the third concerns dogma and can be understood only by faith. The $\tilde{N}$.U. deals with theological arguments as if it were a theological book: the six attributes of God (N.U., vol. 3, lesson 1), God as the creator ( $\tilde{N} . U$. , vol. 1, lessons 7-8) five proofs for the existence of God

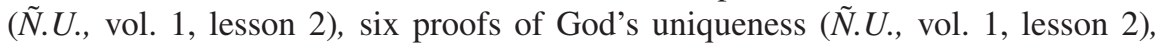
theodicy, namely the relationship between Divine Providence and the existence

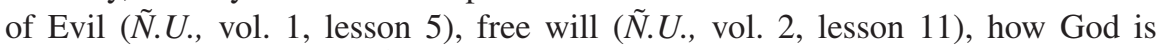
one but in three persons ( $\tilde{N} . U$., vol. 3, lesson 3), Christ as the Incarnation of God ( N. U., vol. 3, lesson 7). Furthermore, as a philosophical work, the $\tilde{N} . U$. tackles important philosophical issues such as the system of cause and effect between God and creation (N. U., vol. 1, lesson 4), the three-layered pyramid of knowledge ( $\tilde{N} . U$., vol. 3, lesson 1), the connotative/denotative meanings of the names of God ( N. U., vol. 3, lesson 1), and the different type of relationships between donors and receivers ( $\tilde{N} . U$. , vol. 3, lesson 2$)$. In the $\tilde{N} . U$., the narrative development follows the books of the Bible. After the first introductory book about theology, the existence of God, and his attributes, the second central book is on cosmogony: the creation of Earth, the choirs of angels, the creation of human beings, and original sin. The third book is a Vita Christi: it starts with the Old Testament's messianic prophecies and Mary's life, then describes the terrestrial life of Jesus until the Last Judgment and the final Resurrection. In the second book there is a long digression on moral teachings, about married life and the education of children $(\tilde{N} . U$., vol. 2, lessons 4-6). It severely criticizes polygamy/polyandry and incestuous relations (N.U., vol. 2, lesson 7) and offers advice on how to escape the treacheries of the Devil (N. U., vol. 3, lesson 15). As a catechism, it lists and explains the five precepts of the Catholic Church (N..$U$., vol. 1, lessons 1), the Ten Commandments (N.U.,vol. 2, lesson 14), and the Sacraments with a detailed explanation of the priesthood (Ñ.U., vol. 2, lesson 15; Nobili, N.U., vol. 3, lesson 19). As a book of prayer, it contains translations in verse form of the Lord's Prayer (Ñ.U., vol. 3, lesson 17), the Hail Mary (Ñ.U., vol. 3, lesson 36), and a Final Salutation to God ( $\tilde{N} . U$., vol. 3, lesson 42). The text also offers answers to difficult questions, like a commentary book, with many detailed explanations on topics such as the six

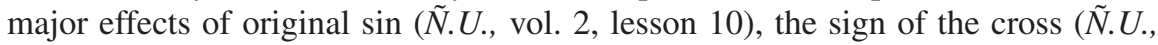
vol. 3, lesson 24), the Baptism of Jesus ( $\tilde{N} . U$. , vol. 3, lesson 13), Jesus' miracles

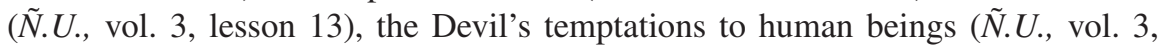
lesson 15), the seven requests in the Lord's Prayer ( $\tilde{N} . U$. , vol. 3, lesson 17), the Ten Commandments ( $\tilde{N} . U .$, vol. 3, lesson 17), the divine mystery of the Holy

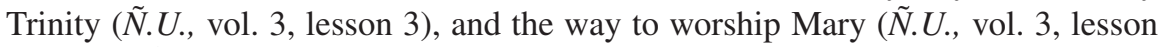
36). The $\tilde{N}$. $U$. begins with vehement criticism of the Hindu gods, like a book for controversy, and also attacks temple worship, certain Hindu religious books, and the Brahman priests (N. U., vol. 3, lesson 18). 
In the $\tilde{N} . U$. the Catholic conceptual grids are carefully shaped according to Tamil and Sanskrit concepts and literature. The book draws a detailed portrait of the Christian God and his attributes, imitating the genre of a Sanskrit Purāna, ${ }^{59}$ referring for example to "the six attributes of God" with a clear reference to the

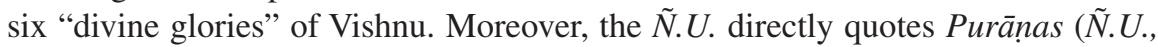
vol. 1, lesson 5) to formulate the controversy and criticize Hindu gods and their veneration; indirectly it recounts many stories from Purānas (such as Śiva Purāṇa, Tiruvillayadal Purāṇa, Sarasvatī Purāṇa, Viṣnu Purāṇa, Kūrma Purāṇa) and from the Sanskrit epic poems Mahabharata and Ramayana. The N. U. develops its theological disquisition on the existence of God and the relationship between God and the creation by combining Catholic concepts (mainly from Thomas Aquinas' Summa Theologiae ${ }^{60}$ and from his commentary on Peter Lombard's Liber Sententiarum $)^{61}$ with conceptual grids drawn from Śaiva literary works such as Civañānapōtam and Civañāna cittiyār (Ñ.U., vol. 1, lesson 2$)^{62}$ while quoting the authority of Bhakti movements and exponents and even making a direct reference to one of the main referents, Śankarācārya (Ñ.U., vol. 3, lesson 1). ${ }^{63}$ The philosophical question of God as an efficient cause and the interesting argument about the denotative/connotative meaning of every name mingles Sanskrit Nyāya Sütras and Aristotelian logic (Ñ.U., vol. 1, lesson 4; N. U., vol. 3, lesson 1). Furthermore, the N.U.'s catechetical teachings, such as the description of married life, are likely shaped on grids derived from Tamil moral books (mostly

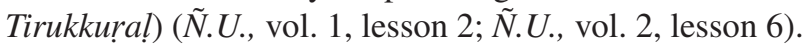

The investigation of the textual grids supports and completes the analysis of the different sources and genres. The division of the books into lessons as teaching units follows the textual grid of Upadeśa, a book of spiritual guidance as provided by a guru, for example the Upadeśasāhasrī by Śańkara. ${ }^{64}$ The work applies the formula sententiarum, a method used in Lombard's Libri Sententiarum for explaining theological questions in scholarly terms using quotations from

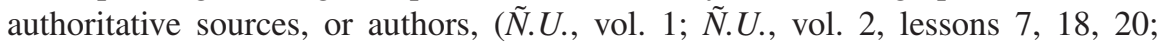
$\tilde{N} . U$., vol. 3, lesson 25). Moreover, the difficult and dogmatic points are explained in terms of a dialectic structure, posing the problem and the solution, as Aquinas does in his Summa Theologiae.

The $\tilde{N} . U$. also resorts to a question-and-answer format $(\tilde{N} . U$. , vol. 2, lesson 7 ) in which the point by point explanations remind us of certain Christian

\footnotetext{
${ }^{59}$ Klostermaier (2002).

${ }^{60}$ Aquinas (1956).

${ }^{61}$ Rosemann (2007).

${ }^{62}$ Goodall (2004).

${ }^{63}$ Isaeva (1993).

${ }^{64}$ Mayeda (2012).
} 
catechisms as well as the Tirukkural ${ }^{65}$ and the Purāna, for example Viṣnu Purāna. In addition, the $\tilde{N}$.U. systematically uses lexical sentence connectors in Tamil, following the sandhi (i.e. euphonic combination) rules of classical Tamil poems and the Tamil grammatical honorific forms, particularly important in a sociolinguistic perspective. Furthermore, in order to underline its authority as a sacred book and to invoke the authority of other religious books the text uses recurrent lexical formulas. ${ }^{66}$ The beginning of the $\tilde{N} . U$. presents the text as a sacred, thaumaturgic religious work and gives readers guidance on how to approaching it, using expressions reminiscent of Bellarmino's Dichiarazione piú copiosa della Dottrina, ${ }^{67}$ Aquinas' Summa Theologiae, the preface of the Roman Catechism, and the Tamil Civañanapōtam. Moreover, Nobili gives explicit advice on how to "listen" to the book, thereby showing that it was meant primarily for oral reception:

The one who comes to listen the catechism must understand first of all what $\tilde{N} . U$. is and which benefits one obtains from the teaching of this supreme knowledge, which is not related to worldly activity or worldly business. ${ }^{68}$

The $\tilde{N} . U$. creates personal attributes for each of the characters in the story, as in the Bible and in Tamil/Sanskrit Puranas, for example: "God (Sarvesran), who is the embodiment of truth" (N. U., vol. 1, lesson 1), "God (Karter), who is an unending ocean" (N. U., vol. 2, lesson 1) "God (Karter), who is omnipotent"

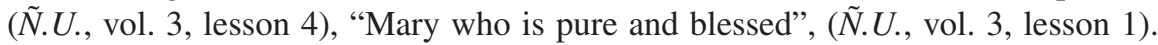
Another important textual feature is the rhetorical apparatus, as the whole book is structured on a dense texture of metaphors drawn from the Tamil Nāyaka court and Christian folk narratives. For example, in the second lesson of the third book, the concept of the Trinity is illustrated using the image of the three folds of a sari:

\begin{abstract}
If you see a sari with three folds, each fold is different to the others but they belong to the same sari, they are three different folds but the sari is one and the same. In the same manner the Universal Divinity (Parāparavastu) is three people, the Father (Pitā), the Son (Sudan), and the Holy Spirit (Ispirittu Sāntu) in one God (Sarveśvara). As we said in the case of three folds in a sari and not three saris, so we have to accept that there are three persons in God: the Father, the Son, and the Holy Spirit, but these three different divine persons must be considered as one Universal Divinity and one God, and not three Gods (Sarveśvara) and three divinities (Vastu). (N.U., vol. 3, lesson 2).
\end{abstract}

\footnotetext{
${ }^{65}$ Tirukkural (Tamil: திருக்குறள்) is one of the Tamil moral books, which is part of Tamil Sangam Period, classical tamil literature. The first Latin translation of Tirukkural, Giuseppe Costanzo Beschi, a jesuit missionary in Tamil Nadu in 1730: G. U. Pope (2012).

${ }^{66}$ For example: "It is said and acceptable truth [...] It is not to be doubted that $[\ldots]$ it is written in the religious book" (Nobili, N. $U$., vol. 2, lesson 17).

${ }^{67}$ Cf.. Bellarmino (1790).

${ }^{68}$ Nobili, N. $U$., vol. 1, lesson 1.
} 
Another explicative metaphor uses the image of the sword and the soul:

The divine mystery of the death of Jesus is that although the soul has left the body, the bondage of the divine person has never been broken. This can be explained by a simile: when the king has the sword in his scabbard, then the sword, the scabbard, and the king are all together. When the king takes the sword from the scabbard, although the sword and the scabbard are separated, the king is holding the sword and the scabbard, which are both with him (Ñ.U., vol. 3, lesson 24).

The set of textual and conceptual grids in $\tilde{N}$. U. mirrors distinctive themes and rhetorical expressions of the culture developed in the Madurai Nāyaka stronghold, including royal biographies, court poems, temple dance dramas, folk tales, and satirical plays. We can also see how Roman Catholic trends and topoi are reshaped according to the missionary's translation strategy: Aquinas's theology, the Jesuit literature of Ratio Studiorum, the Vitae Christi, or Aristotle's philosophy. Concerning the analysis of the textual and conceptual grids, it is not possible to ascribe the $\tilde{N}$.U. to the catechetical genre or any other single genre. Nobili's masterpiece virtually defines a new literary genre, a transcultural compendium for Catholic religious teaching, as its title, which means 'Teaching of Religious Knowledge', promises.

\subsection{The Translation of Religious Concepts as a Process of Domestication vs. Foreignization}

The $\tilde{N} . U$. codifies a pioneering and incisive Tamil-Christian lexicon. Here the author/translator transferred Catholic concepts into the Tamil and Sanskrit languages, placing his translation within a broad spectrum between the two polarities of domestication/foreignization.

The work contains an extensive and interesting vocabulary, domesticated into the Tamil/Sanskrit grids. Some of the religious terminology is borrowed from Sanskrit, for example:

$\bar{A} t m a n=\operatorname{Soul}(\tilde{N} . U .$, vol. 1, lesson 1); Tamil: ஆற்றுமம்,, Ārrumam

Mokṣa = Heaven (Ñ.U.,vol. 1, lesson 1); Tamil: மொக்ஷம்

Naraka $=$ Hell (Ñ.U.,vol. 1, lesson 1); Tamil: நரகம், Narakam

Manita Avatāram = Incarnation, (Ñ.U., vol. 3, lesson 7); Tamil:

மனித அவதாரம் lit. Human Incarnation)

Vètam = Vēda, Religion, Bible (Ñ.U.,vol. 1, lesson 7) (Tamil: வேதம்)

$P \bar{u} j \bar{a}=$ Prayers, Worship (Ñ.U.,vol. 1, lesson 7) (Tamil: புசை) 
Other Catholic concepts are accommodated and domesticated into Sanskrit or Tamil, such as:

Resurrection = Karaiyēru (Tamil: கரையேறு) $(\tilde{N} . U .$, vol. 1, lesson 1); from Karaiyil (Tamil: கரையில் lit. 'the shore'), and êru (Tamil ஏறு lit. 'to climb up') 'to be resurrected'.

Trinity = Tirittuva Ėkattuvam (N.U.,vol. 1, lesson 1) (Tamil: திரித்துவ ஏகத்துவம் < திரி தத்துவன்கல் ஏக தத்துவம் ), Triad and Unity.

Holy church=Tiruccapai (Tamil: திருச்சபை lit. 'Holy Assembly') (N. U., vol. 3, lesson 42).

The process of domestication employed by Nobili is evident if we compare it with the previous Tamil translation of Catholic terminology undertaken by another Jesuit, Henrique Henriques (1520-1600). ${ }^{69}$ In fact, when Nobili settled in the Madurai mission in 1606, Henriques' Thambiran Vanakkam (or Doctrina Christam en Lingua Malauar Tamul, 1578) and Kirīcittiyānni vanakkam (or Doctrina Christiana, 1579) were the first and still the official texts used for teaching native Tamil speakers. ${ }^{70}$ The twelve chapters of Kirīcittiyānni vanakkam are a literal translation into Tamil of a Portuguese catechism, Doctrina Christã, printed in Cochin in 1579. In the translation of the Sacraments, ${ }^{71}$ for example, we can observe the method of domestication employed by Roberto Nobili (R.N.) compared with Henrique Henriques' (H.H) foreignizing translation:

1. Baptism:

H.H.: Vavuttisimu (Tamil: வவுத்திசிமு, from Latin Baptismum, lit. 'baptism')

R.N.: Ñānasnānam, (Tamil: ஞானஸ்நானம், 'bath of knowledge')

2. Confirmation

H.H.: Kirisimarittal (கிரிசிமாரித்தல் from Latin Chrisma, i.e. the chrismal oil used for Confirmation; see also the Italian term 'Cresima')

R.N.: Uruti Pūcutal (Tamil: உறுதிபூசுதல் lit. 'strength', 'anointment')

3. Holy Communion

H.H.: Santu Sacrammentu (Tamil: சாந்து சக்கிறமேந்து from Latin Sanctum Sacramentum, lit. 'Holy Sacrament')

R.N.: Narkarunai (Tamil: நற்கருனை lit. 'good compassion')

4. Confession

H.H.: Compasserital (கொம்பெசாரித்தல் from Latin confessio lit. 'confession')

\footnotetext{
${ }^{69}$ Saulieŕe (1947), p. 506.

${ }^{70}$ Henriques (1963a), (1963b).

${ }^{71} \tilde{N}$. U., vol. 3, lesson 30 .
} 
R.N.: Paccāttāpam (Tamil: பச்சாத்தாபம் lit. 'divine medicine')

5. Extreme Unction

H.H.: Esittirēm Avūñcām (Tamil: எசித்திரேம் அவுஞ்சாம் from Latin extrema unctio, lit. 'extreme unction')

R.N.: Avastai Pūcutal (Tamil: அவஸ்சத பூசுதல் lit. 'final anointment')

6. Priesthood

H.H.: Orutēn (Tamil: ஒருதேன் from Portuguese Ordem, lit. '[priestly] order') ${ }^{72}$

R.N.: Guru Patțam (Tamil: குருப்பட்டம் lit. 'guru appellation')

7. Marriage

H.H.: Mattrimoniu (Tamil: மத்திரிமோனியு from Latin matrimonium, lit. 'matrimony')

R.N.: Vivāham (Tamil: விவாகம் lit. 'marriage')

In order to analyse the process of domestication, we focus on the translation of 'baptism' as ñanna snānam (Tamil: ஞானஸ்நானம்) 'bath of knowledge'. The concept of Snāna (स्नान), 'bathing' is widespread in Sanskrit literature, for instance in the Purānas. It was a common belief that every religious disciple should take six kinds of ritual baths in the course of his life. ${ }^{73}$ Nobili, however, did not adopt the Sanskrit terms referring to any of these baths. This is another case of non-alignment, which was central to Nobili's strategy of religious translation: the Jesuit did not translate baptism with Kriyā snāna (ceremonial bath), for example, but rather transferred the sense of baptism (as a ritual act of bathing for gaining the religious knowledge required for the soul to be saved) in the newly created compound word $\tilde{n} \bar{a} \underline{n} a$ snānam, thus realizing a dynamic equivalence. Here we can see the process of translation in action: the translator separates the sense from the significance, ${ }^{74}$ and the isolated sense is reshaped and domesticated in the receiving language. The result is a dynamic equivalence and a transcultural concept. This is not totally domesticated in the semantic of the Tamil/Sanskrit culture (such as Mokșa, Vétam or Pūjā), but it uses a Sanskrit semantic box to enclose a Catholic concept. The process of translation implies a multi-dimensional, meta-linguistic and performative act. ${ }^{75}$ This is a recreation, reproduction, and refraction that is guided by the assumption that the source will somehow still be present in the reformulated version.

In a few other cases, for example the translation of 'Holy Spirit', we find a foreignizing concept, with the transliteration from the Latin/Portuguese Spiritus Sanctus/Espírito Santo in the Tamil scripts (Ispirīttu Sāntu - Tamil: இஸ்பிரீத்து சாந்து).

\footnotetext{
${ }^{72}$ It is interesting to observe that in this case Henriques certainly modelled his foreignizing Tamil translation on a Portuguese word (ordem) and not on the corresponding Latin form, namely ordo. We can rule out even the possibility of a derivation from cases other than the nominative (i.e. ordo), as they all have the stem ordin-: ordinis (genitive), ordini (dative) etc.

${ }^{73}$ They are Nitya snāna ('daily bath'), Naimittika snāna ('incidental bath'), Kāmya snāna ('desirable'), Kriyā snāna ('ceremonial'), Kriyāinga snāna ('bathing only the limbs used for rites'), and Malakarșaṇa snāna ('bathing to purge excrement') (Agni Purāṇa, Chapter 155).

${ }^{74}$ Frege (1892).

${ }^{75}$ Most relevant is Burke (2007). Cf. also Cronin (1996); Hsia (2007); Lutter (2014).
} 
A survey of the list of domesticated and foreignizing translations suggests that, if the Tamil Christian lexicon in the $\tilde{N} . U$. is mainly characterized by a domesticated method of translation, there are nonetheless a few cases of foreignization, such as in the translation of Easter (Paska பஸ்க, from Latin Pascha in $\tilde{N} . U$. , vol. 3, lesson 18), Christ (Kiristu கிறிஸ்து in $\tilde{N} . U$. , vol. 3, lesson10.), Anti-Christ (Anti kiristu, அந்திக் கிறிஸ்து in Ñ.U., vol. 3 lesson 37) and Holy Spirit (Ispirīttu Sāntu - Tamil: இஸ்பிரீத்து சாந்து). As mentioned above, there are also cases of formal or gloss translations for the words God, Jesus, Mary, and the angel Gabriel, Elizabeth's praise of Mary (N.U., vol. 3, lesson 5.), Zachary's prayer Benedictus (N.U., vol. 3, lesson 6), and the prayer "Our Father" ( $\tilde{N} . U$., vol. 3, lesson 17). Here the method is characterized by a word-byword translation and a gloss translation which presents a commentary with pointby-point explanations.

Between the two poles of domestication and foreignization, there is a vast repertoire of translations, but these poles mark the boundaries. Most early modern Catholic catechisms were translated word-by-word from a pre-existing pattern (an example is the case of the Portuguese catechism Doctrina Christã by Marcos Jorges, translated in the Jesuit missions around the world) ${ }^{76}$ often with the religious terminology merely transliterated. Nobili's work marked an important transition, as he translated and transferred the Catholic missionary model, literature, and lexicon into the Tamil language and culture. For these reasons, Nobili's method raised objections and was examined in Cochin and Goa in 1610 and once again in Goa in 1619 before being approved by Pope Gregory XV in 1623. However, the case of Nobili was not the result of individual action alone, but fits well into missionary and ecclesiastical dynamics, both at a local level (in the Jesuit Malabar province and in the Archbishopric of Goa) and on a global scale (at the papal court and in the congregations in Rome). In addition, the peripheral position of Madurai, albeit connected to the wider world by a dense epistolary network, facilitated the Jesuit's local initiative and gave him greater freedom of action. I would argue that the foreignization of a few terms and the gloss translation of direct speeches and prayers constitutes a combination of (1) a narrative and stylistic choice of translation (in this way the author endorses the source's concepts and brings the audience to the source) and (2) a political and theological position to demonstrate orthodoxy and adherence to the teachings of the Roman Church. This conservative approach aimed to maintain conformity with Roman orthodoxy and to avoid religious censure that could eventually lead to an inquisitorial process.

There is an important passage in Nobili's Responsio in which the Jesuit tried to substitute the term 'Holy Spirit' with a Tamil concept, explaining that by advice of the Provincial Father he used the Tamil word only in the Profession of Faith, in some prayers, and in the Sign of the Cross, but not in the Sacraments. ${ }^{77}$ Although Nobili's translation is an example of domestication, the passage just mentioned

\footnotetext{
76J. M. P. Dos Santos (2016).

${ }^{77}$ Cf. Dahmen (1931), pp. 152-53.
} 
reveals how his translation was influenced by a narrative of orthodoxy and by the power hierarchy. As it is written in the Bible (Matthew 12:31-32): "And so I tell you, every kind of sin and slander can be forgiven, but blasphemy against the Spirit will not be forgiven. Anyone who speaks a word against the Son of Man will be forgiven, but anyone who speaks against the Holy Spirit will not be forgiven, either in this age or in the age to come."

\subsection{Conclusion}

Using our model of cultural translation as an analytical tool, the investigation clearly reveals the structure of Nobili's process of translation and his missionary strategy. His work aimed to demonstrate the adaptability of the Roman Catholic doctrine to a Tamil context and to domesticate it into the religious and cultural setting of Tamil Nāyaka society. This method was target-oriented and specifically addressed the South Indian audience. It was meant to be understood and to generate an equivalent effect. In this operation Nobili carefully selected, negotiated, accommodated, and shaped topics and practices from both Roman Catholic and Tamil/Hindu linguistic and cultural codes. This process of selection, accommodation, and re-codification neither established any identity nor appropriated existing models, but generated dynamic equivalencies and new forms of transcultural dynamics. The outcome was not the result of the translator's act alone, but rather a combination of different actors and powers who were locally and globally interconnected: the Tamil addressees, the new Christian community, the ecclesiastical hierarchies in India and Europe, the Jesuit order, and the Portuguese monarchy and its ecclesiastical patronage (Padroado) of the Asian missions.

When Nobili reached Madurai in 1609, he followed the initial Jesuit strategy and instructions, which aimed to convert the elite of Madurai society, based on the idea that only the conversion of the cultural elite made possible the effective evangelization of the rest of society. Therefore he directed his translation to the Brahmanical elite, as we can infer from the analysis of the specific dynamic equivalence which he chose and from his mimetic model of a Brāhman Sannyāsin. Furthermore, the Madurai Catholic mission was an independent local enterprise under the protection of local Nāyaka kings. Nāyaka kings were Telugu warriors, Balija cultivators, and affiliated to merchant castes. In Madurai, Nobili's mimetic Brahmanical model failed to capture the Nāyaka symbolic universe of heroes. The mission's demographic base was mostly made up of non-Brähman converts: Nāyakas, merchants, warriors, and farmers. Therefore Nobili tried to accommodate his teaching to the fluidity and the existential modes demanded by the ethos of the Nāyakas. But his model of a Catholic Brāhman Sannyāsin, addressing a multi-ethnic audience with different social affiliations, did not manage to capture the complexity of Madurai hierarchical structure. In the later stages of the Madurai mission, Nobili's companions and successors actually replaced the Sannyāsa model with that of a Pandāram (a non-Brāhmanical priest). 
On a macro level, Nobili's experiment reveals the complexity and the transcultural dimension of early modern Catholicism in its process of negotiating cultural trends, religious practices, and beliefs. This complex texture shaped modern identities as transcultural. Transculturality de-constructs the monolithic image of cultural identity and embraces the dynamism of cultural and religious encounters. Nobili's strategy of evangelization was no innovative creation ex novo, but rather the result of a cultural encounter between a Catholic priest in the process of Imitatio Christi and the Nayaka ethos of Madurai society. In this encounter, the interlocutors shaped themselves as transcultural subjects, crossing cultural boundaries and creating new forms of resistance.

\section{References}

\section{Unpublished}

Archivum Romanum Societatis Iesu, Roma (ARSI).

A. Laerzio to Acquaviva 'Relatione di Madurè', 20 Novembre 1609 ARSI GOA 54a, ff. 2-16.

B. A. Buccerio to Aquaviva 3 October 1610, ARSI, Goa 51, ff. 110-15 (1st via) 116-22 (2nd via), lat (3rd via) in Goa 53, ff. 40a-40y. Cf. Rajamanickam 1972, S. 23.

C. Vico, A. to Laerzio, A., 27 May, 1611, in Laerzio, A, to Aquaviva, C, Cochin (It.), 25 November, 1611, ARSI, Goa 54a, ff. 93-129.

D. Vico, A. to Laerzio, A., 27 May, 1611, in Laerzio, A, to Aquaviva, C, Cochin (It.), 25 November, 1611, ARSI, Goa 54a, ff. 93-129.

Roberto Nobili, Catecismus Madurense (Ñāna Upadēsam), Goa State Central Library, I-1a, $\mathrm{I}-1 \mathrm{~b}$.

\section{Published}

Abé, Takao. 2017. Christian Catechisms and Practice in Japan in the Era of the Jesuit Mission. An Intercultural Approach. In Translating Catechisms: Entangling Christian History, eds. Antje Flüchter and Rouven Wirbser, 285-307. Leiden: Brill.

Apter, Emily. 2006. The Translation Zone: A New Comparative Literature. Princeton: Princeton University Press.

Aquinas, Thomas von. 1956. Summa Theologiae: Cura Et Studio Sac. Petri Caramello. Cum Textu Ex Recensione Leonina. 3 vols. Rom: Marietti.

Aranha, Paolo. 2010. Sacramenti o saṃskārāḥ? L'illusione dell'accommodatio nella controversia dei riti malabarici. Cristianesimo nella storia 31 (2): 621-646.

Bachmann, Peter R. 1972. Roberto Nobili 1577-1656: Ein Missionsgeschichtlicher Beitrag zum christlichen Dialog mit Hinduismus. Würzburg: Institutum Historicum.

Bassnett, Susan. 2013. Translation Studies. London: Routledge.

Bayly, Susan. 1992. Saints, Goddesses, and Kings. Muslims and Christians in South Indian Society, 1700-1900. Cambridge: Cambridge University Press.

Bellarmino, Roberto Francesco Romolo. 1790. Dichiarazione piu' copiosa della dottrina cristiana composta per ordine della S.M. Di Papa Clemente VII. Roma: Nella Stamperia de Michele Puccinelli.

Bhabha, Homi K. 1994. The Location of Culture. London: Routledge. 
Boyer, Pascal. 2007. Religion Explained. The Evolutionary Origins of Religious Thought. New York: Basic Books.

Burke, Peter. 2007. Cultures of Translation in Early Modern Europe. In Cultural Translation in Early Modern Europe, eds. Peter Burke and Ronnie Po-Chia Hsia, 7-38. Cambridge: Cambridge University Press.

Chakravarti, Ananya. 2018. The Empire of Apostles. Religion, Accommodatio, and the Imagination of Empire in Early Modern Brazil and India. Oxford: Oxford University Press.

Cronin, Michael. 1996. Translating Ireland. Translation, Languages, Cultures. Cork: Cork University Press.

Dahmen, Pierre. 1931. Robert De Nobili: L’Apôtre Des Brahmes: Première apologie, 1610. Paris: Éditions Spes.

Dos Santos, J.M.P. 2016. Illustrations of Doutrina: Artwork in the Early Editions of Marco Jorge's Doutrina Cristã. Bulletin of Portuguese/Japanese Studies 2:149-167.

Ferroli, Domenico. 1955. The Jesuits in Mysore. S.1: s.n.

Flüchter, Antje. 2018. Translating Jesuits - Translation as a Useful Tool to Explore Transculturality. In Engaging Transculturality. Concepts, Key Terms, Case Studies, eds. Christiane Brosius, Diamantis Pangiotopoulos, and Susan Richter, 199-214. London: Routledge.

Flüchter, Antje, and Giulia Nardini. 2020. Threefold Translation of the Body of Christ. Concepts of the Eucharist and the Body Translated in the Early Modern Missionary Context. Publication pending.

Frege, Gottlob. 1892. Über Sinn und Bedeutung. Zeitschrift für Philosophie und philosophische Kritik 100:25-50.

Goodall, Dominic. 2004. Preface. Explanatory Remarks About the Śaiva Siddhānta and Its Treatment in Modern Secondary Literature. In The Parākhyatantra. A Scripture of the Śaiva Siddhānta, ed. and trans. Dominic Goodall, xiii-xxxiv. Pondicherry: Institut français de Pondichéry and École française d'Extrême-Orient.

Henriques, Henrique. 1963a. Kiricittiyani Vanakkam or Doctrina Christam (1579). Tuttukudi: Tamil Literature Society.

Henriques, Henrique. 1963b. Thambiran Vanakkam or Doctrina Christam en Lingua Malauar Tamul (1578). Tuticorin: Tamil Literature Society.

Hsia, Ronnie Po-Chia. 2007. The Catholic Mission and Translations in China, 1583-1700. In Cultural Translation in Early Modern Europe, eds. Peter Burke and Ronnie Po-Chia Hsia, 39-58. Cambridge: Cambridge University Press.

Isaeva, Natalia. 1993. Shankara and Indian Philosophy. Albany: State University of New York Press (SUNY).

Israel, Hephzibah. 2019. Translation and Religion: Crafting Regimes of Identity. Religion 49 (3): 323-342.

Juneja, Monica, and Christian Kravagna. 2013. Understanding Transculturalism. Monica Juneja and Christian Kravagna in Conversation. In Transcultural Modernism, eds. Fahim Amir et al., 22-33. Berlin: Sternberg Press.

Klostermaier, Klaus. 2002. Hinduism: A Short Introduction. Oxford: Oneworld.

Koselleck, Reinhart. 2007. The Practice of Conceptual History. Timing History, Spacing Concepts. Stanford: Stanford University Press.

Koster, Cees. 2010. Comparative Approaches to Translation. In Handbook of Translation Studies, eds. Y. Gambier and L. van Doorslaer. Amsterdam: John Benjamins Publishing.

Lefevere, André. 1998. The Gates of Analogy. The Kalevala in English. In Constructing Cultures. Essays on Literary Translation, eds. Susan Bassnett and André Lefevere, 76-89. Clevedon: Multilingual Matters.

Lefevere, André. 2002. Composing the Other. In Post-Colonial Translation. Theory and Practice, eds. Susan Bassnett and Harish Trivedi, 75-94. London: Routledge. 
Lutter, Christina. 2014. What Do We Translate When We Translate? Context, Process, and Practice as Categories of Cultural Analysis. In The Trans/National Study of Culture. A Translational Perspective, ed. Doris Bachmann-Medick, 155-167. New York: De Gruyter. Mayeda, Sengaku. 2012. A Thousand Teachings: The Upadeśasāhasrī of Śañkara. SUNY Press

Nardini, Giulia. 2017. Roberto Nobili's Vivāha dharma: A Case of Cultural Translation. In Translating Catechisms: Entangling Christian History, eds. Antje Flüchter and Rouven Wirbser, 223-251. Leiden: Brill.

Nida, Eugene Albert. 2012. Principles of Correspondence. In The Translation Studies Reader, ed. Lawrence Venuti, 126-140. Abingdon: Routledge.

Nobili, Roberto de. 1966. Ñana Upadesam (தததுவ தபாதகர ஞானுபததச). Ed. Savarimuthu Rajamanickam 3 vols. Tuticorin: Tamil Literature Society.

Olivelle, Patrick. 2005. Manu's Code of Law. A Critical Edition and Translation of the ManavaDharmasastra. Oxford: University Press.

Pope, G. U. 2012. The Sacred Kurral of Tiruvalouva Nayanar, with Latin Translation by Fr. Beschi. New Delhi: Asian Educational Services.

Pratt, Mary Louise. 1991. Arts of the Contact Zone. In Profession, 33-40. Modern Language Association.

Rajamanickam, Savarimuthu, ed. 1971. Adaptation [by] Roberto de Nobili. Palayamkottai: De Nobili Research Institute.

Rajamanickam, Savarimuthu. 1972. The First Oriental Scholar. Tirunelveli: De Nobili Research Institute.

Rosemann, Philipp W. 2007. The Story of a Great Medieval Book. Peter Lombard's "Sentences". Toronto: University of Toronto Press.

Said, Edward William. 1996. Kultur und Identität - Europas Selbstfindung und Einverleibung der Welt. Lettre International 34:21-25.

Saulière, Augustine. 1947. Red Sand: A life of St. John de Britto, S.J. Martyr of the Madura Mission. Madura: De Nobili Press.

Saulière, Augustine. 1995. His Star in the East, Revised \& Re-Edited by S. Rajamanickam. Madras: De Nobili Research Institute.

Schleiermacher, Friedrich. 1816. Ueber die verschiedenen Methoden des Uebersetzens. Berlin: Königliche Akademie der Wissenschaften.

Subrahmanyam, Sanjay. 1997. Connected Histories. Notes Towards a Reconfiguration of Early Modern Eurasia. Modern Asian Studies 31(3):735-762.

Thurston, Edgar, and K. Rangachari. 1909. Castes and Tribes of Southern India (I-VII voll.). Library of Alexandria.

Venuti, Lawrence, ed. 2012. The Translation Studies Reader. London: Routledge.

Welsch, Wolfang. 1995. Transkulturalität. Zwischen Globalisierung und Partikularisierung. Zeitschrift für Kulturaustausch 45(1):39-44.

Welsch, Wolfgang. 1999. Transculturality. The Puzzling Form of Cultures Today. In Spaces of Culture. City, Nation, World, eds. Mike Featherstone and Scott Lash, 194-213. London: Sage.

Županov, Ines G. 1999. Disputed Mission. Jesuit Experiments and Brahmanical Knowledge in Seventeenth-Century India. Delhi: Oxford Press.

\section{Further Reading}

Aldrige, Alan. 2000. La religione nel mondo contemporaneo. Bologna: Il Mulino.

Benjamin, Walter. 1972. Die Aufgabe des Übersetzers. In Gesammelte Schriften, ed. Walter Benjamin, 9-21. Frankfurt a. M.: Suhrkamp.

Berger, Peter, Grace Davie, und Effie Fokas. 2010. America religiosa, Europa laica? Bologna: Il Mulino. 
Brauner, Christina, und Antje Flüchter. 2017. Introduction. The Dimensions of Transcultural Statehood. Comparativ 24 (5): 7-27.

Buden, Boris, et al. 2009. Cultural Translation. An Introduction to the Problem, and Responses. Translation Studies 2 (2): 196-219.

Filoramo, Giovanni. 2004. Che cos'è la religione? Torino: G. Einaudi.

Nida, Eugene Albert. 2003. The Theory and Practice of Translation. Leiden: Brill.

Pechelis, Karen. 2014. The Embodiment of Bhakti. Oxford: Oxford University Press.

Pratt, Mary Louise. 1992. Imperial Eyes. Travel Writing and Transculturation. London: Routledge.

Open Access Dieses Kapitel wird unter der Creative Commons Namensnennung 4.0 International Lizenz (http://creativecommons.org/licenses/by/4.0/deed.de) veröffentlicht, welche die Nutzung, Vervielfältigung, Bearbeitung, Verbreitung und Wiedergabe in jeglichem Medium und Format erlaubt, sofern Sie den/die ursprünglichen Autor(en) und die Quelle ordnungsgemäß nennen, einen Link zur Creative Commons Lizenz beifügen und angeben, ob Änderungen vorgenommen wurden.

Die in diesem Kapitel enthaltenen Bilder und sonstiges Drittmaterial unterliegen ebenfalls der genannten Creative Commons Lizenz, sofern sich aus der Abbildungslegende nichts anderes ergibt. Sofern das betreffende Material nicht unter der genannten Creative Commons Lizenz steht und die betreffende Handlung nicht nach gesetzlichen Vorschriften erlaubt ist, ist für die oben aufgeführten Weiterverwendungen des Materials die Einwilligung des jeweiligen Rechteinhabers einzuholen.

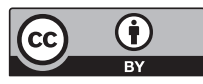

